IRSH 52 (2007), pp. 35-58 DOI: I0. I0I7/S0020859007003 I I 2

(C) 2007 Internationaal Instituut voor Sociale Geschiedenis

\title{
"Cartooning Capitalism": Radical Cartooning and the Making of American Popular Radicalism in the Early Twentieth Century
}

\author{
MICHAEL C OHEN
}

Summary: During the first two decades of the twentieth century, a mass culture of popular radicalism - consisting of various socialist, industrial unionist, anarchist, Progressive, feminist, black radical and other movements - arose to challenge the legitimacy of corporate capitalism in the United States. This article considers the role of radical cartoonists in propagandizing for, and forging unity within, this culture of popular radicalism. By articulating a common set of anti-capitalist values and providing a recognizable series of icons and enemies, radical cartoonists worked to generate a class politics of laugher that was at once entertaining and didactic. Through a discussion of the works of Art Young for The Masses, Ryan Walker's cartoons for the socialist newspaper, Appeal to Reason, and the proletarian humor of Joe Hill and the IWW, this article argues that radical cartooning did not merely provide comic relief for the movements, but was an active force in framing socialist ideology and goals in a revolutionary age.

There can be no question about leftwing humor being "radically" different, for that is precisely what its creators intended it to be. It is humor invigorated by the hope of human progress, satire enlivened by the passion for social justice, and wit aimed with unerring skill at the stupidity or indifference of those who cherish the strange delusion that this is 'the best of all possible worlds.'

$$
\text { International Treasury of Leftwing Humor (1945) })^{\mathrm{I}}
$$

It's just that cartoons are most aesthetically pleasing when they manage to speak truth to power, not when they afflict the afflicted.

Art Spiegelman $(2006)^{2}$

I shot a cartoon into the air;

It fell - I know not where,

But after all there's no regret,

The idea may be going yet.

Art Young (1928) 3

I. International Treasury of Leftwing Humor (Winnipeg, BC, 1945).

2. Art Spiegelman, "Drawing Blood: Outrageous Cartoons and the Art of Outrage", Harper's Magazine (June 2006), p. 45.

3. Art Young, On My Way: Being the Book of Art Young in Text and Picture (New York, 
"The true art of the untrammeled cartoonist is now being developed", wrote Eugene V. Debs in I9I2, "and he will be one of the most inspiring factors in the propaganda of the revolution". ${ }^{4}$ Freely combining the humorous with the instructional, the angry with the ironic, radical cartoonists helped draw (in both senses of attracting and representing) hundreds of thousands of Americans into a mass socialist movement that grew to become the single greatest challenge to the domination of corporate capitalism in US history. The simply drawn, politically pointed, and cheaply reproduced black line cartoons of Art Young, Ryan Walker, Maurice Becker, Robert Minor, William Gropper, Lou Rogers, Ernest Riebe, Ralph Chaplin, and scores of others gave the movements for industrial unionism, socialism, populism, progressivism, anarchism, black radicalism, feminism, and anti-militarism a kind of visual exuberance and common set of anti-capitalist values that artistically blended an angry if playful outrage with a sense of collective idealism.

Radical cartoons helped to forge a class-conscious politics of laughter that at its best riotously mocked the values of the capitalist system. These cartoons set out to puncture the self-assumed legitimacy of a newly consolidated corporate ruling class, and dramatized radical solutions to the injustices suffered by those both physically and mentally enslaved by capitalism's mass produced delusions of right, necessity and "The American Dream". The collectivity borne of a shared laugh at these clowning portraits of overstuffed plutocrats, the complicit and manipulated puppets in government and civil society, and especially the comically deluded working-class "Mr Blocks" and "Harry Dubs", made a considerable contribution to representing the radical movement's aesthetics and ideology while shoring up the fragile unity across the multitudinous and often contentious politics of the American Left.

Rather than dwell on the divisions of native-born and immigrant workers, direct action versus electoral socialism, progressive reform or revolutionary militancy, radical cartooning stripped the movements and their enemies to their core ideologies, depicting an epic struggle between "plutocracy and democracy", human solidarity versus unrestrained greed. Radical cartoon humor thus offered instruction, persuasion, and entertainment, providing an excellent medium for what contemporary Cultural Studies describes as "cultural resistance", or what social movement theorists have termed "framing social protest": the creation of cultural practices, ideological models, and aesthetic strategies designed to empower popular intellectuals and ordinary people to understand the social world

I928), p. 235.

4. Eugene Debs, Introduction to Ryan Walker, Art Young, Walter Crane, Balfour Kerr et al., The Red Portfolio: Cartoons for Socialism (Girard, KS I9I 2). 


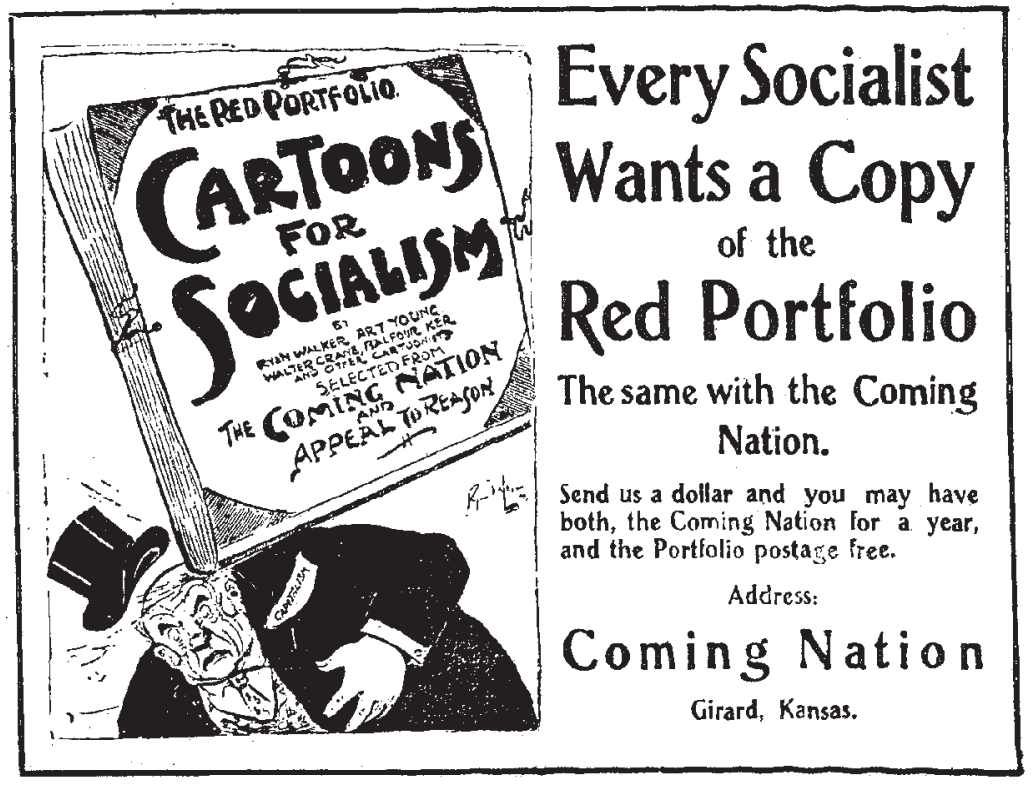

Figure r. Ryan Walker's slapstick allegory of cartoon activism appears in an advertisement for the Red Portfolio: Cartoons for Socialism (Girard, KS, I9I2). This is the first collection of radical cartoons in US history.

with the explicit intention of transforming it. 5 For many of the cartoonists, socialist humor simply pushed the possibly crazy belief that laughing at the capitalist system was a necessary element in defeating it. In his introduction to The Red Portfolio, an early collection of radical cartoons, Socialist party presidential candidate Eugene Debs comically insisted, "Cartooning capitalism is far more inspiring than capitalistic cartooning."

In this essay I want to consider the social and artistic contribution of cartooning to the radical social movements of Progressive-era America (1900-I922). First, I will mark out the distinct contribution of cartooning - both ideologically and aesthetically - to a mass culture of popular radicalism, before looking more closely at three overlapping areas of radical humor: the cosmopolitan ironies of Art Young, the grass-roots

5. Sociologists and social movement theory have developed the concept of "framing social protest" as a way of understanding how popular intellectuals and ordinary people come to understand the world in order to change it. This concept, based on the theories of Antonio Gramsci, is similar in many ways to the concepts of "hegemony" and "cultural resistance" favored by Cultural Studies. On the concept of framing and popular intellectuals, see Michiel Baud and Rosanne Rutten, "Introduction," in idem (eds), Popular Intellectuals and Social Movements: Framing Protest in Asia, Africa, and Latin America, International Review of Social History, Supplement I 2 (Cambridge, 2004), pp. I- I8.

6. Debs, Introduction to The Red Portfolio. 
socialist humor of Ryan Walker and the Appeal to Reason, and the revolutionary proletarian songs and cartoons of the Industrial Workers of the World (IWW or Wobblies).

\section{THE CULTURE OF POPULAR RADICALISM}

For the generation of American radicals who rose and fell between the Haymarket bombing of I886 and the long Red Scare of I917-I922, the generation who founded the People's Party (I892), the Socialist Party (I90I), and the IWW (I905), who embraced the radical press, who marched in opposition to the political trials of Big Bill Haywood, Tom Mooney, and Sacco and Vanzetti, who built the International Labor Defense (ILD) and the American Civil Liberties Union (ACLU), the American Left forged its deepest influence and broadest solidarity through a vibrant culture of popular radicalism. Taken together, this culture of rebels and rabble-rousers collectively built a nationwide revolutionary movement, dedicated to challenging the legitimacy of monopoly capitalism while defending the right of a free citizenry to organized dissent and rebellion in the face of persistent private, military and judicial repression.

The historian Paul Buhle has argued that there never really was one, singular American socialism, but rather a diverse array of often competing socialisms. ${ }^{7}$ Each strain offered up its own vision of the forthcoming socialist future and provided its own critique of the capitalist system. However, most factional divisions were based on tactical priorities as each group built up distinct strategies ranging from the general strike to propaganda to electoral politics. Official leaders and theoreticians had a far greater tendency to encourage factionalism, infighting and division than unity: The anti-radicalism of American Federation of Labor president Samuel Gompers, the anti-black racism of Socialist Party congressmen Victor Berger, the invectives and infighting of Socialist Labor Party leader Daniel DeLeon, or the IWW's syndicalist hostility to electoral politics of any kind, to cite but a few examples, were persistent threats to political unity across labor and Left organizations.

However, below the level of Socialist Party maneuvering and detailed scientific socialist studies of American capitalism, the political energy of pre-World-War-I American popular radicalism built itself up around an influential core of working-class organic intellectuals and a popular culture of mass education and vulgar Marxist propaganda. ${ }^{8}$ As IWW leader Big

7. Paul Buhle, Marxism in the United States: Remapping the History of the American Left (New York, 1987). Also see James Weinstein, The Decline of Socialism in America: 1912-1925 (New Brunswick, NJ, 1984).

8. The term "popular radicalism" is derived from the work of E.P. Thompson, who deploys this term to describe an "intellectual culture" and "political consciousness" of the plebean masses as "the articulate consciousness of the self-taught"; E.P. Thompson, The Making of the English 
Bill Haywood loved to tell his audiences: “I've never read Marx's Capital, but I've got the marks of capital all over my body."9 Popular radicalism was a largely evangelical culture of autodidacts and charismatic leaders that flourished among a generation of agitators who - like Haywood - could not get past the first chapter of Capital; melodramatic journalistdetectives; the non-violent striker attacked by Pinkerton detectives; the crowd of immigrant workers marching to a massive, multi-lingual legal defense rally; the hobos, timberbeasts, and bindlestiffs who rode the rails to fill prison cells during free speech fights; urbane reformers and folksy populists alike who opposed the "Trusts"; and the striking factory girl who learned her class-consciousness from cheap pamphlets, soap-box oratory, and comic strips. Every ideological shade and faction of the Left's historical bloc contributed to this popular radical culture, from the investigative journalism of Mary Heaton Vorse and John Reed, the popular fiction of Jack London and Upton Sinclair, the legal defense work of Clarence Darrow, and the passionate leadership of Eugene V. Debs, Mother Jones, and Emma Goldman.

But more than any mass movement before or since (with the possible exception of the culture radicals of the 1960s), cartooning and humor played a key role in the growth and unity of the radical movements. Though the labor and reform movements of the nineteenth century were not without their comedians - like the literary humorists Russell B. Nye, Marietta Holley, and Mark Twain, who was an outspoken anti-imperialist and died an avowed socialist - it was not until the early twentieth century that radical cartoonists and humorists became central figures in the mass social movements themselves. As with any movement that worked to unite so many disparate populations and factions, socialist humor took many forms, ranging from the Southwestern wit and wisdom of Oscar

Working Class (New York, 1966), p. 7I I. The concept of the "organic intellectual" is borrowed from the writings of Antonio Gramsci, who describes this new intellectual leader as an "active participation in practical life, as conductor, organizer, 'permanent persuader' and not just a simple orator"; Antonio Gramsci, "The Intellectuals", in Selections from the Prison Notebooks, Quintin Hoare and Geoffrey Nowell Smith (eds) (New York, I 971), p. Io. And historian Donald Sassoon provides a powerful definition of pre-1914 "vulgar Marxism" as consisting of three basic points: (I) The capitalist system is unfair because the wage relation disguises a fundamentally unequal relationship of economic power between employer and worker; (2) history proceeds through a constantly evolving series of stages and struggles, and while each stage corresponds to a specific economic system and ruling class, the current stage of capitalism is not everlasting; and (3) the working class is a fundamentally homogeneous class regardless of superficial divisions of race or nation: workers the world over have the same interests in common and they must collectively organize to bring about a more just world. This simple trinity of vulgar Marxism embraces the Marxist economic theory of exploitation and surplus value, the theory of class struggle and historical materialism, and the political agendas of working-class internationalism. Donald Sassoon, One Hundred Years of Socialism: The West European Left in the Trwentieth Century (New York, I996), pp. 5-8.

9. Haywood quoted in Buhle, Marxism in the United States, p. 95. 
Ameringer, the proletarian word play of T-Bone Slim, or the urban traditions of radical Yiddish humor. ${ }^{10}$ Yet it was through cartooning that the socialist movement found one of its most important unifying cultural elements.

Of the hundreds of radical papers that appeared before World War I, all but the most genteel or theoretically sophisticated routinely published cartoons and humor. American socialists and radicals embraced movement cartooning with near universal adoration of its visual delights and its usefulness as propaganda. Indeed, radical artists before World War I faced none of the aesthetic and political controversies that plagued later (particularly communist) efforts to discipline both the artist and the medium. ${ }^{\text {II }}$ Several prominent radical papers specialized in cartooning, like the early Socialist Party magazine The Comrade, the Midwestern radicalism of The Coming Nation, or Art Young's postwar satire magazine, Good Morning. The many Wobbly papers, Solidarity, the Industrial Worker, and the One Big Union Monthly published thousands of cartoons, many of which were drawn by unknown "fellow workers" who drew their cartoons on spare scraps of paper and submitted them under comical pseudonyms or just their red card membership number, their real names now lost to history. The Masses and The Liberator, though broadly ignored in their time, featured such fine cartooning that art historians now recognize their contributors to be among the most significant modern artists working at the turn of the century. ${ }^{\mathrm{I} 2}$

In fact, cartooning was so important in the culture of popular radicalism that beyond their artistic contributions and prominence as politically committed artists, many cartoonists stood out as political leaders of the radical movements and in turn became targets of state repression. Art Young repeatedly ran for state and local offices with the Socialist Party in New York City, and during World War I Young, Max Eastman, Jack Reed

Io. The existing scholarship on radical American humor between the death of Mark Twain and the arrest of Lenny Bruce is very thin. The best collection is Paul Buhle (ed.), Labor's Joke Book (St Louis, MO, 1985). Also see Buhle's entry on "Humor", in The Encyclopedia of the American Left, 2nd edn (New York, 1998), pp. 337-34I; T-Bone Slim, Juice is Stranger Than Friction, Franklin Rosemont (ed.) (Chicago, IL, I992); Ray Ginger, Ray Ginger's Jokebook about American History (New York, 1974).

I I. The congenial relationship between American radical cartoonists and the movements they were committed to (and sometimes directly led) is underscored by the controversy that erupted between George Grosz and the German Communist Party in the I920s and I930s over the direction of his art, satire, and cartooning in general. German communists attempted to restrain Grosz's ridicule and venom towards the ruling classes in the name of respectability and socialist realism, leading to a significant communist-led campaign against his cartooning as a political art. See Barbara McCloskey, George Grosz and the Communist Party: Art and Radicalism in Crisis, 1918 to 1936 (Princeton, NJ, 1997).

I2. Rebecca Zurier, Art for The Masses: A Radical Magazine and its Graphics, 19II-19I7 (Philadelphia, PA, I988). 
and the rest of the editorial board of The Masses faced two federal trials for treason and conspiring against the war effort. John Sloan, art editor of The Masses and founder of the Ashcan School of explicitly poetic urban realist painting, twice ran for the New York state assembly in I9IO and I9I3, and a judgeship in I 914 on the Socialist ticket. In addition to drawing hundreds of cartoons and authoring the labor anthem "Solidarity Forever", Ralph Chaplin was editor of the IWW's official organ Solidarity when he was sentenced to twenty years in federal prison at the mass trials of IWW leaders in I9I 8 . And despite producing some of the most memorable cover images for The Masses and Alexander Berkman's short-lived paper The Blast, Robert Minor gave up his artistic career to become a leading apparatchik in the CP-USA. ${ }^{\text {I }}$

Unlike a theoretical analysis or encouragements to vote the SP ticket, radical cartoons had the ability to reach the millions of uneducated, semiliterate, and the vast non-English-speaking immigrant sectors that comprised the American working class. Therefore, the key contribution of radical cartooning to the culture of popular radicalism can be found on a formal level. Beyond the surface diversity of individual styles, radical cartooning established a coherent visual vocabulary of class struggle and socialist possibility that influenced the entire movement. Most cartoons were single panel black ink drawings with a caption, although some popular series appeared as multi-panel strips. While some artists, especially those working in the Masses, chose to work with an ink brush or crayons on slate board for a slightly more painterly style, the traditional techniques of etching or engraving - so typical of the bourgeois aesthetics of the capitalist press of the nineteenth century - proved both formally regressive in their fetishistic emphasis upon detail and photo-realism, as well as being prohibitively expensive for the shoe-string budgets of most radical papers. Despite the fact that several movement cartoonists - including Art Young and Ryan Walker - did receive professional artistic training, their chosen style emphasized a democratic simplicity that left the emphasis upon the message over the messenger. And because individual cartoons were often reprinted in several papers across the ideological spectrum, it created a nationwide audience and a shared sense of humor across the movements.

However, this aesthetic simplicity belies a complex formal ideology in which radical cartoons simultaneously carried a humorous intent with an explicitly didactic ambition. Radical newspapers in the pre-World-War-I era brimmed with reductive melodramas or angry satires imagined as vivid political allegories. Broad social forces and classes were easily reduced to

13. Richard Fitzgerald, Art and Politics: Cartoonists of the Masses and Liberator (Westport, CT, 1973); Ralph Chaplin, Wobbly: The Rough-and-Tumble Story of an American Radical (Chicago, IL, 1948); Joseph North, Robert Minor: Artist and Crusader (New York, 1956); Alice Sheppard, Cartooning for Suffrage (Albuquerque, NM, 1994). 


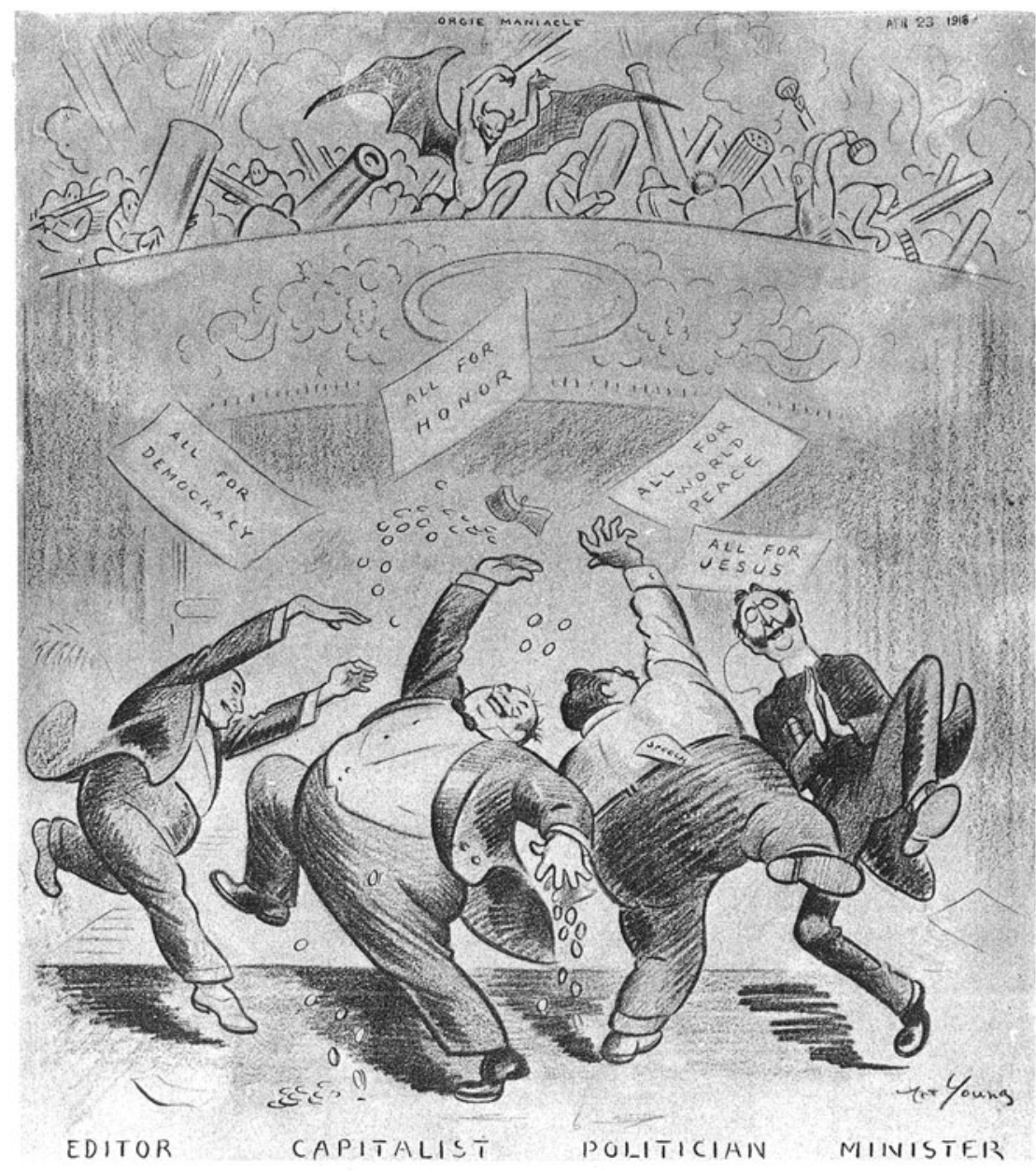

HAVING THEIR FLING

Figure 2. Art Young, "Having their Fling”, The Masses (September 1917). This is one of several anti-war images published in the The Masses for which Young faced two federal treason and conspiracy prosecutions under the Espionage Act during World War I. Both trials ended with hung juries, however the government did succeed in suppressing the The Masses with censorship.

individual stock characters like the bloated and pompous Capital, the sniveling and stooping politician, the broad-chested and pig-snouted police, the harlot commercial press, the shriveled and cruel robed figure of Justice, the foolish and degraded non-union worker, and on heroic occasion, the forthright and courageous radical. This allegorizing impulse seemed a necessary expression of the era of "robber barons", trusts, the blustering reaction of Teddy Roosevelt, and domination by "plutocrats". 
With overwhelming fortunes and personalities like J.P. Morgan and John D. Rockefeller dominating the turn of the century social imaginary, it was difficult for most to accept Karl Marx's theoretical admonition that capitalists must be deprived of their individual will and seen merely as an instrument of an economic logic, or, in Karl Marx's words, as "capital personified and endowed with consciousness and a will". ${ }^{14}$ So, contrary to the strict materialist logic of Marx's position (but true to his frequently gothic imagery of Mr Moneybags or blood-sucking vampires), popular radical cartooning insisted on embodying capitalism as the malevolent and comic plutocrat, always full of dramatic possibilities.

By elevating their level of abstraction beyond that of a specific political contest or controversy (the Democrat versus Republican political cartooning that was the typical domain of the partisan urban newspaper world), radical cartoons frequently sought to represent or reveal the nature of capitalism as a whole by providing a singular image of the social totality. "We thought it time to satirize the whole capitalistic works", recalled Art Young upon launching Good Morning in 1919. "Not with subtle analysis of conditions in essays and the like, but with straightforward exposé in cartoons and comment, and with comedy rampant." Is This allegorizing and totalizing impulse, imbedded in a culture of popular propaganda, is perhaps the real genius of radical cartooning.

\section{ART YOUNG}

Arthur Henry Young, known to the world as Art Young, was probably America's most widely respected and deeply beloved radical cartoonist. Through his distinct style of blending a cultivated visual simplicity with a potently ironic comedy, Art Young stood out as one of the most eloquent talents in the American socialist movement as well as a subversive humorist uniquely capable of reaching into the mainstream of the American press. Between I9I 2 and 1934 Art Young's cartoons appeared in every major radical journal, and he became the central figure in American radicalism's most important magazines of art and politics, including The Masses, The Liberator and his own brilliant, yet short-lived humor magazine, Good Morning. Art Young's cartoons specialized in challenging the ideological platitudes of his era of capitalist excess and imperialism, all represented on a level of abstraction and allegory that made his work instantly accessible, effortlessly humorous, and radically didactic. Today, Art Young is sadly all but forgotten; none of his books

I4. Karl Marx, Capital: A Critique of Political Economy, Volume I (I867) trans. Ben Fowkes (New York, 1976), p. 254.

I 5. Art Young, His Life and Times, John Nicholas Beffel (ed.) (New York, 1939), p. 353. 

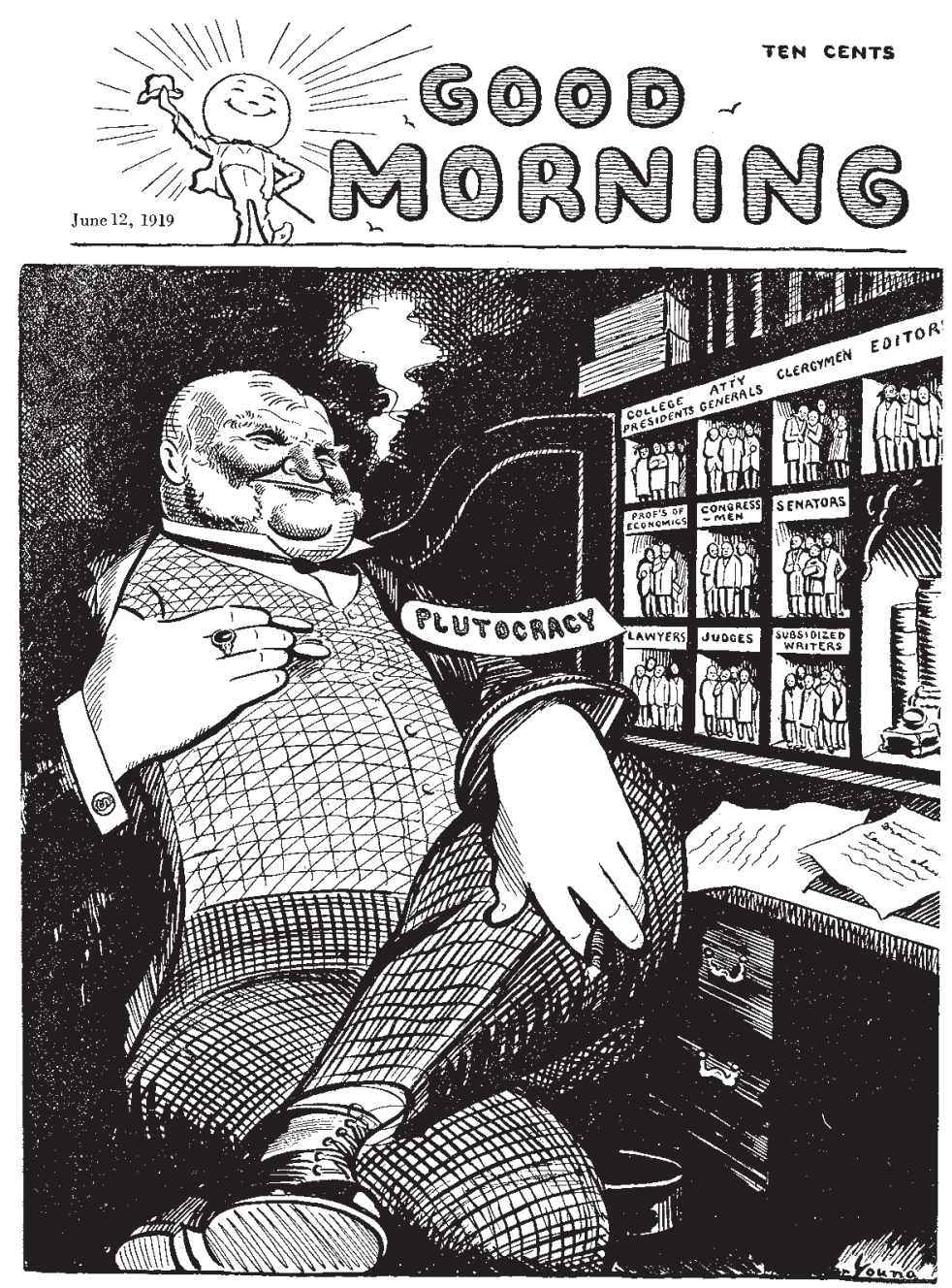

Figure 3. Art Young, "System", Good Morning, I 2 June 1919. Young imagines the corruption of civil society by monopoly capitalism as a giant desk in which the plutocrat simply pulls out his tools - judges, editors, professors of economics - from their pigeon holes and applies them in his own self-interest as so many paperclips and pens.

remain in print, no recent biography, collections or exhibitions of his work have ever been attempted. ${ }^{16}$ Yet his body of cartooning is as politically relevant now as it was when Art drew it nearly a century ago.

Art Young was born into a successful petty bourgeois family in the small town of Monroe, Wisconsin in I866. Young chose graphic or cartoon art 


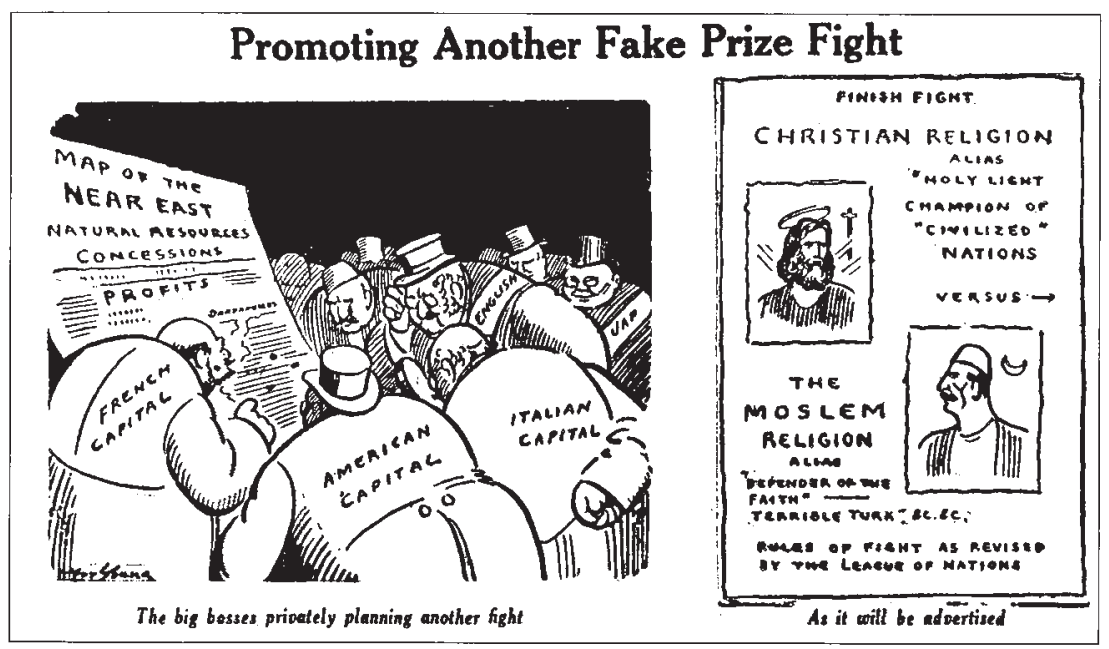

Figure 4. Art Young, "Promoting Another Fake Prize Fight", Appeal to Reason, 28 October I922.

from an early age as his "road to recognition" because, he recalled, painting could only have limited influence whereas "a cartoon could be reproduced by simple mechanical process and easily made accessible to hundreds of thousands. I wanted a large audience." 17 After selling his first cartoon to Judge magazine in 1883 , Art enrolled at Chicago's Academy of Design and took a job in the editorial offices of the Evening Mail. In I888, Art Young moved to New York where he worked for Joseph Pulitzer's New York World. After spending a year studying drawing with Adolphe-William Bourguereau in Paris, Art Young took an offer from the Chicago InterOcean in I892, a Republican paper where Young had the opportunity to work with the legendary artist, Thomas Nast.

Nast was America's best-known political cartoonist who had famously vanquished Boss Tweed and Tammany Hall with his attacking cartoons. Nast's influence can clearly be seen in Art's visual style; but more importantly, though Young was suspicious of Nast's personal politics (which ran towards an extreme nativism), Nast provided proof that cartoonist had the power to affect real political change. "I have always felt," wrote Art in 1927, "that there is more power in my talent than in the mind of a statesman". ${ }^{8}$ Yet this faith in the power of his work faced constant frustration while working in the capitalist press. "They don't want creeds or isms", wrote Young of the capitalist press, "they want a cartoonist to make faces at the world". ${ }^{19}$ 
Young's conversion to socialism happened gradually, but it appears to have crystallized around the events of the Haymarket bombing of i 886 . Amidst a citywide general strike, a rally held in Chicago's Haymarket Square ended tragically when someone threw a bomb into a line of police who had ordered the peaceful rally to disperse. This explosion, and the subsequent arrest of eight anarchists, set off the first nationwide "red scare" and deeply divided the city and the country along class lines. Within the anti-union, anti-radical press maelstrom that followed the bombing, Art Young clung to his paper's belief that the anarchists were part of a conspiracy to destroy civilization itself. "My social awareness remained undeveloped", he wrote, "I had no perspective on the human conflict, and had not found out how to connect up an effect with its underlying cause." ${ }^{20}$ Yet, Young did get rather close to the case, traveling to Joliet prison where he drew highly dignified portraits of the eight men mere days before one of the men committed suicide and four others were hanged.

Years later, Art Young expressed deep regret for his political ignorance during the Haymarket trial and for his vicious attacks on Illinois Governor John Altgeld (at his editor's instructions) for pardoning the remaining anarchists in I 893. Altgeld's death in 1902 proved a catalyst for Young, leading him to re-read Altgeld's eloquent statement of pardon, where Young came to the unsettling conclusion that as a newspaper cartoonist he had not only contributed to the state murder of the Haymarket martyrs but to the political destruction of the honorable Altgeld as well. ${ }^{21}$ At the age of thirty-six, Art realized that he was part of the problem, and that his life and work needed to change:

And with this feeling [of shame over attacking the Haymarket anarchists and Gov. Altgeld], I poised in my mind some other questions as to the soundness of beliefs I had long held, based upon copy-book maxims drilled into one generation of American children after another: 'Merit wins .... Survival of the fittest .... You can't change human nature .... The best people.... The poor you have with you always ...' and the whole long line of rubber-stamp moral precepts. What were these but glittering emblems set up by the moneyed class to serve its own purpose? Born bourgeois, my brain had been filled from infancy with the nonsense of super-patriotism, with the lily-white virtues of imperialism added in due time. I had harbored these false values because I didn't know any better. I had been a drifter, innocent and sheep-minded long enough. ${ }^{22}$

American socialism loved conversion stories, and the effort to reproduce this revelation in the mind of his audience now became the central subject of Art's increasingly radical cartooning. Bourgeois platitudes, superficial

20. Young, His Life and Times, p. 8I.

21. Art Young, "Haymarket Square, Chicago, May 4, I886", New Masses (2 May 1939), pp. I I-I 3; "From Art Young's Notebook", New Masses (I I April 1939), pp. I0-I3.

22. Young, His Life and Times, p. $22 \mathrm{I}$. 
economic doctrines and other capitalist "copy-book maxims" provided Art Young with captions, while his drawings delved deeply into the reality behind such appearances. A radical irony became his primary comic idiom as he found his favorite means to attack the voices of capitalist ideology by ridiculing its faiths and aping its tone.

Let us consider the nature of Art's comedy more closely by looking at a single page of Good Morning from I92 I. Below the banner - depicting a distant if harmonious industrial utopia framed by the working tools of the cartoon artist - we find a simple expression of the Marxist theory of value and a dramatization of the ethical impasse brought on by the monopolization of basic human necessities under the capitalist system. At the center of the image sits a large and sinister looking man labeled "business," a dollar sign hanging from his neck like a dog-tag. Our businessman imperiously occupies an ocean pier, dressed in the heights of Newport beach swim fashion with his toes dangling leisurely in the water. Behind him, a mountain of life preservers (labeled "necessities of life") looms uselessly. "Business" thus sits as an icon of unfeeling capital, sneering cruelly through a cloud of smoke at a mass of people tossed about helplessly in the waves. The caption simply states what any good bourgeois economist recognizes as an iron law of economic necessity: "Plenty of Demand - But No Market".

With abundant wit and concision, Art Young's image takes on the supposedly scientific laws of supply and demand: held up by economists as the only ethical and natural arbiter of value made possible by the genius of the marketplace. Young's critique, a careful reduction of Marx's theory of value and commodity production, is twofold. First, in taking the laws of supply and demand at face value, Young depicts the capitalist system as a grotesque catastrophe in which plentiful (overproduced even) resources are incapable of being matched up with overwhelming need. In this landscape of economic logic that which cannot be sold (exchange-value), has no (use) value at all. Not only are we witness to the drowning of countless people, but presumably the capitalist himself is doomed to fail in his foolish insistence on selling his products in such an unsustainable market. Secondly, Young's drama explicitly denaturalizes the economic system by insisting upon the human and social cost behind the supposedly impersonal laws of exchange-value. In Young's image, "supply and demand" are revealed to bear the burden of real ethical choices in which profits are more valuable than people and economic logic serves only as a pseudo-scientific justification for unfettered greed and the inhuman refusal to aid the suffering.

Clearly, Young calls out to us, there is a better way to organize society. If only we could get rid of that big lug on the pier, we could use the productive capacity built by capitalism to ensure that everyone will be able to keep their heads above water. This example is not comic art that dishes 


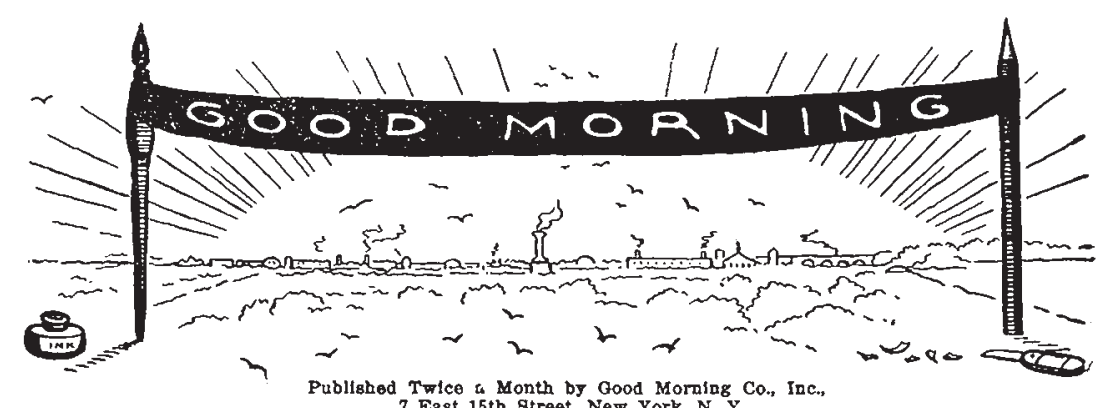

7 East 15 th Street, New York, N. Y.

\begin{tabular}{ll}
\hline Vol. III. No. 11. & September, 1921. \\
\hline
\end{tabular}

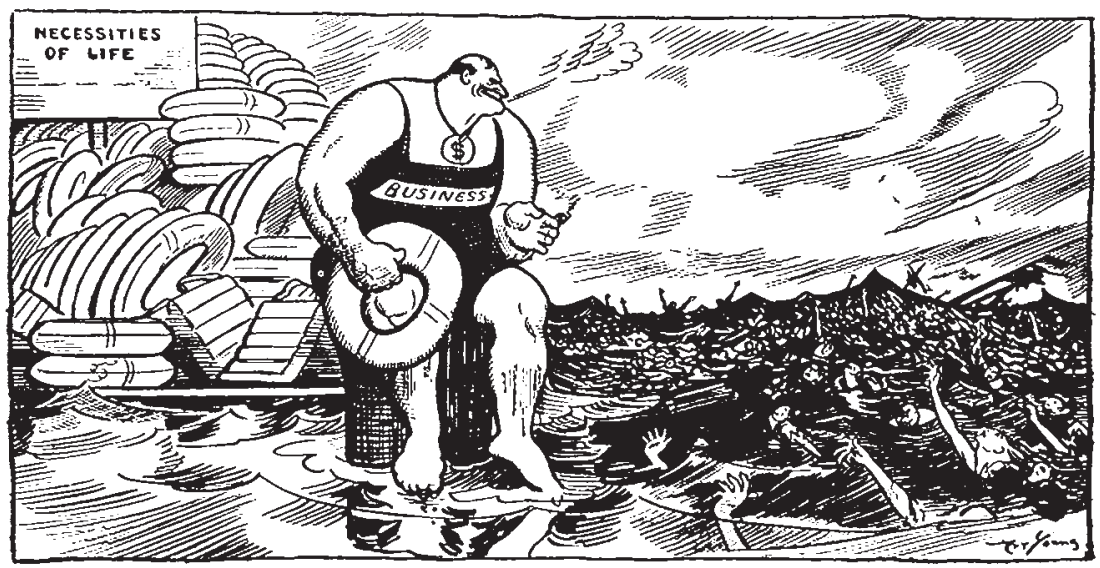

Figure 5. Art Young, Good Morning, III, no. I I (September I92I).

up a quick chuckle, but instead offers us a comic scenario as a vehicle for far more complex economic ideas and a direct challenge to identify with the ethical position presented. Yet, the affiliation which the image offers us is non-sectarian, but relies upon a basic politics of class difference and a universal socialist ethic. "I was much more interested always in drawing cartoons which would strike at a vulnerable point in the armor of the common enemy", writes Art, "than in battling over the fine points of tactics". ${ }^{23}$

Art's last major work, Art Young's Inferno published in 1934, was his third book-length updating of Gustave Dorés famous engravings of Dante's Inferno. With so many arch-capitalists having earned their way into Hell, the capitalists have effectively taken over, deposed old man Satan 


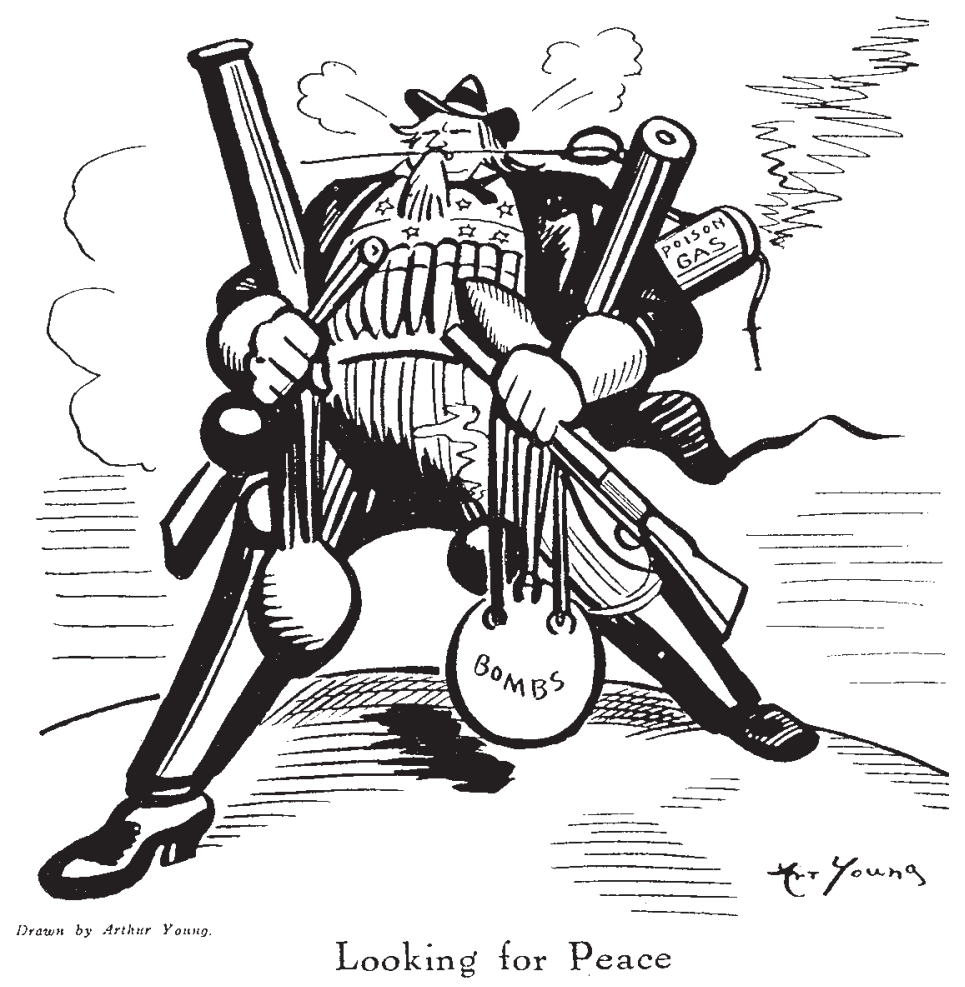

Figure 6. Art Young, "Looking For Peace", The Masses (December I9I5). Amidst the US intervention in the Mexican Revolution, Art Young and The Masses took a strong stand against rising American militarism.

and transformed Hell into the last refuge of capitalism. "Let me tell you something", one of Hell's resident capitalists tells Young,

Capitalism on earth is doomed. It spread over the world for hundreds of years, now Hell is the only available place left - the last outpost, and believe me, we are going to make a good job of it - no fool notions. They say, "We live and learn", but we had to die to learn. ${ }^{24}$

Young finds that capitalism seems made to thrive in Hell. Everything in this new Hell is privatized and operated by a monopoly, maximizing both profits and inconvenience. The Hell Water Power Co. is the single most powerful company in Hell, and their fire department (with twenty book keepers to each fireman) won't put out your burning home unless you pay for the water first. The subways are all privately owned and desperately 
How to cure World-Unrest

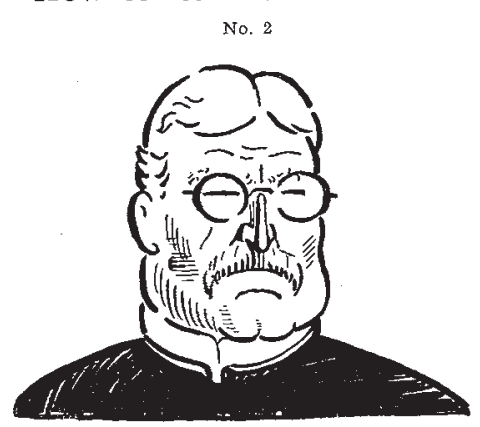

The Reverend A. Jawbunk.

Denver, Colo.-The Reverend A. Jawbunk, a local minister of prominence, preached an eloq :ent sermon yesterday on "Social Unrest, the Peril of the Twentieth Century."

Mr. Jawbunk says, "Parlor-socialists should be imprisoned for life and communists who advocate the rule of labor should be tarred and feathered daily until cured." Mr. Jawbunk announced that his sermon next week would answer his critics"Was Jesus really poor and opposed to aristocracy?" The Reverend Jawbunk has proof that Jesus was an aristocrat and wanted the poor to stay where they belong.

\section{How to cure World-Unrest}

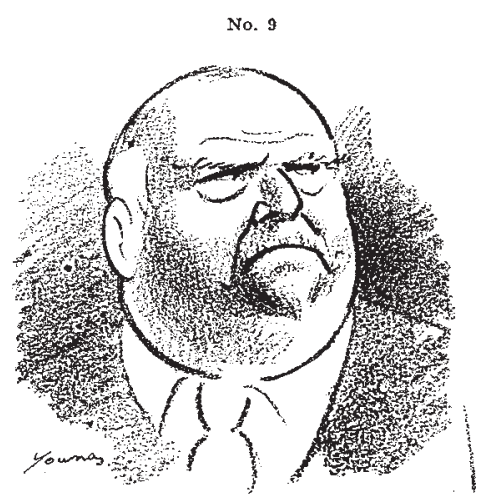

Henry B. Allmine.

St. Louis, Mo--Henry B. Allmine, leading Capitalist of this city, says, "The cure for discontent is hunger." Mr. Alfmine has closed down his extensive manufacturing plant, throwing out of employment two thousand men and women. He says that when his workers come pleading for their old jobs at reduced wages - "they will bring with them the spirit of love and gratitude and will be cured of their discontent."

Figure 7. Art Young, "How to Cure World-Unrest \#2 and \#9", Good Morning (1920).

inefficient and insufferable, parks charge admission and cool breezes cost a dollar, highways charge a toll each and every mile. Public toilets or "comfort centers" in Hell all require cash, hospitals will only treat sinners who can pay for their treatment ("the fraternal racket of gouging the sick"), and real-estate speculating has grown so fevered that caves are rented for large sums. "All of the natural resources are owned by monopolists", comments Young with an absurd calm. "Even the center of gravity located below the ninth circle has been purchased by a syndicate of speculators. They hold all rights to the discovery, and it is rumored they will try to move it to a more profitable location in Upper Hell."2s

As a working artist, Art Young's commitment to socialism was never just a product of an intellectual or abstract critique, but was born of his profoundly personal sense of solidarity with all workers, be they pushers of pencils or shovels, who must sell their lives and their talents to a system that exploits not just their time and energy, but their ideals, their creativity, their artistry for the ignoble goal of making money for someone else. 
"Artists and ditch-diggers are alike producers, whatever the tools used pen, pencil, and brush, or pick and shovel”, wrote Young,

Those who can handle these tools must work for those whose business it is to make a profit. And there is no legal limit to profit making. So long as both sides are compelled to struggle for money as their objective, it will be a class war, a war between those who produce and those who prod the producer to work harder and cheaper. ${ }^{26}$

Much like William Morrison or Oscar Wilde, Art Young's commitment to socialism was born not just of his desire to see the working class liberated from wage slavery, but an entire culture freed from the bonds of commodification, a creativity unfettered by the needs to satisfy a system built upon exploitation.

\section{RYAN WALKER AND THE APPEAL TO REASON}

Perhaps the only radical cartoonist more prolific than Art Young was Ryan Walker. Born in 1870 in rural Kentucky, Walker represented a key voice of Midwestern populist-socialism through the thousands of cartoons he provided to The Comrade, The National Rip-Saw, The New York Call, The Coming Nation and, most importantly, the Appeal to Reason. ${ }^{27}$

The Appeal to Reason was published between I 895 and 1922 in the small town of Girard, Kansas, and quickly became the most important newspaper in the history of American socialism: it commissioned and first published Upton Sinclair's The Jungle as a serial; it hired Eugene Debs as its lead editorialist and managed his endless speaking tours and presidential campaigns; and always went looking for the good fight. Explicitly evangelical in its approach to winning converts to the cause of socialism, the Appeal imagined itself to be a grass roots movement unto itself, and by I9I3 the Appeal reached a peak circulation of 750,000 (coinciding closely with the peak in the Socialist Party vote), making it the largest circulating national paper of its era and the largest circulating left-wing paper in American history. "The Appeal is an agitation sheet - that and nothing more", proudly wrote the paper's founder J.A. Wayland in 1905 , "I am an agitator. The propaganda of Socialism is my specialty." 28

Ryan Walker's cartoons fit perfectly with the Appeal's sensibility, and he propagandized for the paper in print and on stage. Like a socialist

26. Young, His Life and Times, p. 397.

27. B.O. Flower, "Ryan Walker: A Cartoonist of Social Protest”, Arena (April i905), pp. 392406. In his later years, Walker joined the Communist Party, worked as a staff cartoonist for the Daily Worker, and finally died while on tour of the Soviet Union in 1932.

28. J.A. Wayland, "Short-hand Talks by the 'One Hoss”, Appeal to Reason (May i 3, I905). On the history of the Appeal to Reason, see John Graham (ed.), "Yours for the Revolution": The Appeal to Reason, I895-1922 (Lincoln, I990). 


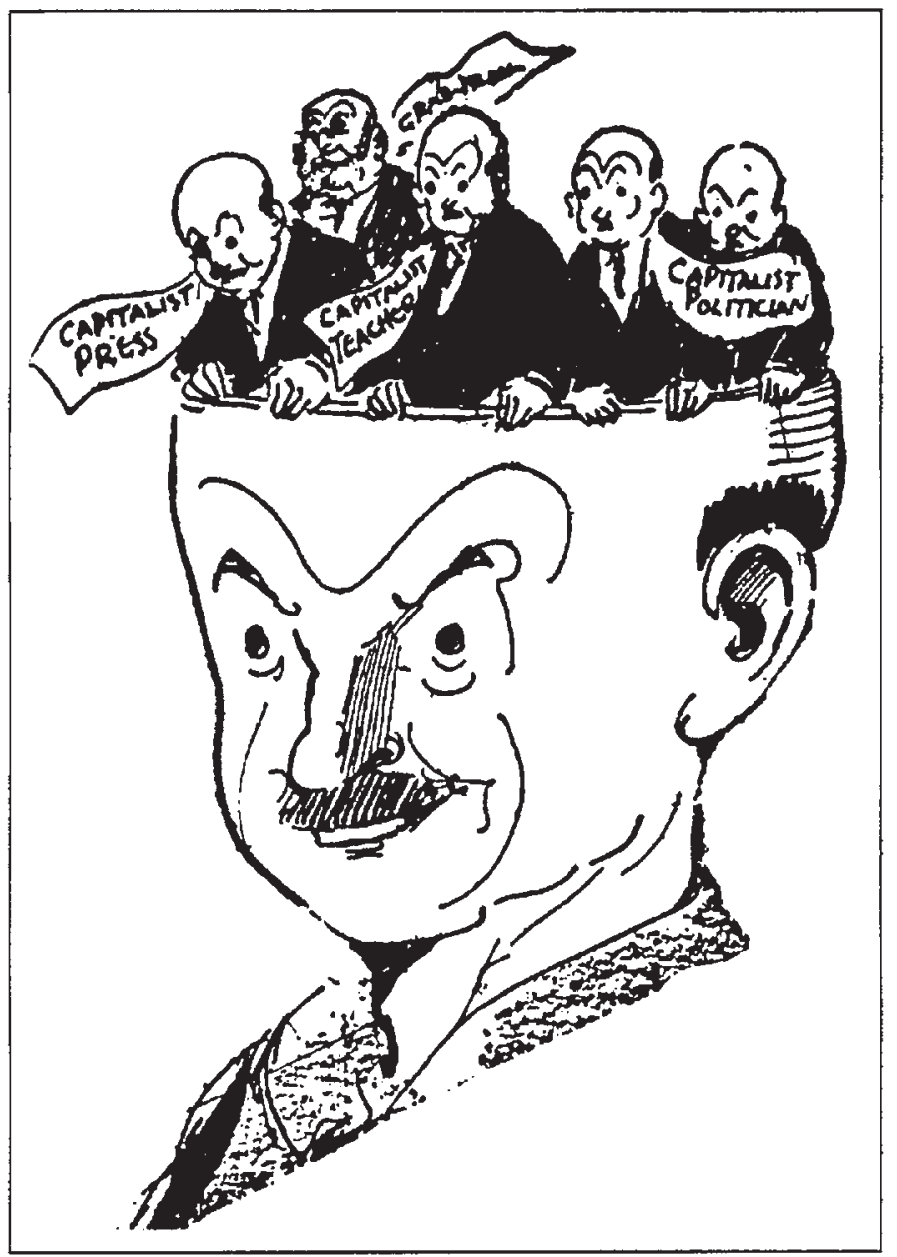

"Who Does Your Thinking For You?"

Figure 8. Ryan Walker, “Who Does Your Thinking For You?”, Appeal to Reason, 24 June 1922. Published by J.A. Wayland, the Appeal was popular radicalism's most important voice of propaganda and socialist self-education.

Thomas Nast, Walker produced several cartoons a week for the Appeal (and later for the daily New York Call) commenting on that week's events in allegorical cartoon dramas and paneled comic strips. The Appeal also organized national tours of socialist speakers to evangelize for the Socialist Party and sell subscriptions. Walker traveled the country performing a kind of socialist vaudeville act that he called "Chalk Talks on Socialism". In a mixture of stand-up comedy, comic art, and soap-box propaganda, Walker would stand before a large chalkboard and entertain 
his audience with story and rhetoric, all spontaneously illustrated with interactive drawings. Designed to explain the basic philosophy of socialism to a small town audience, Walker's chalk talks, like his cartoons, helped grow the grass-roots of Debsian socialism into a national movement.

Walker's most lasting legacy was the creation of the first radical comic strip, featuring the misadventures of Henry Dubb, a hapless worker who rejects socialism, unions and every other avenue to improve his meager lot in life. Dubb's wife and child seem to know - or quickly come to discover - that what Henry believes to be the just and natural order of things is in fact a corrupt social system, maintained through (slapstick) violence and the stupidity of the Henry Dubbs of the world. Of course, Henry never learns and finds himself arrested, out of a job or simply made to look the fool once again, resulting in his weekly exclamation: "I'm a Henry Dubb!?” The character of Henry Dubb provided endless iterations of socialism's class politics of laugher, enabling working-class readers to laugh harmlessly at the "false consciousness" of their fellow-worker, while reinforcing their own sense of solidarity with every week.

Ryan Walker was a major figure in creating an alternative socialist culture, a culture which utilized technologies, advertising strategies and cultural forms of the capitalist system, but struggled to build them upon a different set of values. Thus the Socialist Party utilized the dominant form of electoral party politics to create a socialist alternative to the plutocratic major parties. In this same vein, the Appeal to Reason can with some truthfulness be read as a socialist version of "yellow journalism", selling sensationalism and pressing circulation as a revolutionary Pulitzer or Hearst might have. Never much of a formal innovator, Walker utilized the basic forms of newspaper cartooning - the topical editorial and the character driven comic strip (as well as vaudevillian stage comedy) - to serve the cause of the cooperative commonwealth. Walker's gift proved to be in the thoroughness with which he politically reoriented these forms, pressing them in to spirited revolutionary service that was at once didactic and thoroughly comic.

\section{THE IWW, JOE HILL, AND MR BLOCK}

"The working class and the employing class have nothing in common", declares the opening line of the famous Preamble of the IWW. The rest of the manifesto speaks of the economic class struggle, the need for industrial unionism, and the IWW's goal of taking "possession of the earth and the machinery of production, and abolish the wage system". But this "nothing in common" of which the Wobblies insist is not just the "nothing" born of dialectically opposed economic positions of exploiter and exploited. It is 


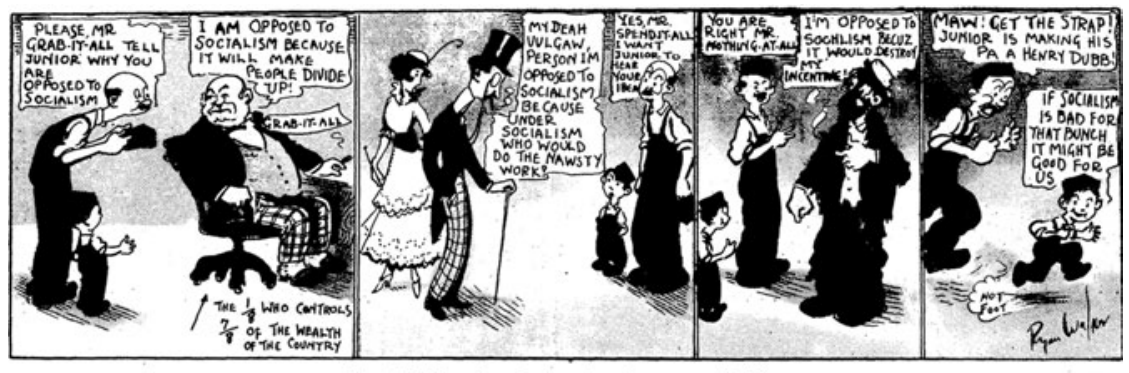

Henry Dubb Introduces Junior to Some Opponents of Socialism

Figure 9. Ryan Walker, New Adventures of Henry Dubb (Chicago, IL, I9I 5 ).

also the "nothing in common" of culture and values, of language, religion, art, poetry and song. And it is the "nothing in common" of joy, pleasure, and of a radically contradictory sense of humor. The Wobblies had, in the words of historian Franklin Rosemont, "no aptitude for being dull”, and the radical comedy of the IWW deliberately and divisively evoked a class-consciousness, both laughing with the militant working class and at the decadent ruling class, marking that unbreachable and self-defining divide of class and class consciousness by what one finds funny and what one sees as a threat. ${ }^{29}$

No one embodied the Wobbly's cultural project better than Joe Hill, songwriter, cartoonist, and martyr for the One Big Union. Chasing jobs from coast to coast as an immigrant itinerant worker, Joe Hill's legend emerged slowly out of the hobo jungles and Wobbly papers as he anonymously published dozens of songs and cartoons. But Hill was suddenly thrust into the national spotlight in I9I5 when he was arrested and executed in Utah for a double murder. The IWW denounced this as a "frame-up", claiming Hill as a cultural warrior whose cartoons and songs the capitalist state sought to silence with a firing squad. Joe Hill wrote many of the best-known, and funniest songs in the Little Red Song Book, including "Mr Block", "Rebel Girl", and "Casey the Union Scab". Inspired by the worlds of vaudeville, hobo humor, and proletarian laughter, Hill borrowed the tunes for his songs from both the revival tent hymnal and the popular hits of Tin-Pan Alley. However, his songs do not qualify as parodies; rather, Joe Hill's songs are often cruel attacks upon the reactionary spirit of his original sources. Thus Sanford Fillmore Bennett's pious "In the Sweet Bye and Bye" provides the tune for the atheistic "The Preacher and the Slave" in which the "long haired preachers" instruct their hungry prospective converts: "You'll get pie in the sky when you die." "If

29. For more on IWW culture and cartoons, see Franklin Rosemont, Joe Hill: The IWW E the Making of a Revolutionary Workingclass Counterculture (Chicago, IL, 2003); Rosemont, "A Short Treatise on Wobbly Cartoon", in Joyce L. Kornbluh (ed.), Rebel Voices: An IWW Anthology (Chicago, IL, 1998); and Sal Salerno, Red November, Black November: Culture and Community in the Industrial Workers of the World (Albany, NY, I989). 
a person can put a few cold, common sense facts into a song and dress them (the facts) up in a cloak of humor to take the dryness off of them", wrote Joe Hill in a letter, "he will succeed in reaching a great number of workers who are too unintelligent or too indifferent to read a pamphlet or an editorial on economic science." 30

But perhaps Joe Hill's most popular song was "Mr Block", based upon the IWW's favorite cartoon series.

Please give me your attention, I'll introduce to you

A man that is a credit to "Our Red White and Blue";

His head is made of lumber, and solid as a rock;

$\mathrm{He}$ is a common worker and his name is Mr Block

And Block he thinks he may

Be President some day.

Oh Mr Block, you were born by mistake,

You take the cake,

You make me ache.

Tie a rock on your block and then jump in the lake,

Kindly do that for Liberty's sake!

Ernest Riebe created Mr Block and his comic misadventures ran in Wobbly papers from I9I 2 through the I920s. In I9I3 Riebe collected twenty-four Mr Block cartoons into a pamphlet marking it as the first radical comic book in American history..$^{3 \mathrm{I}}$ Little is known of Riebe, but he was born in Germany, lived in Minneapolis, and focused all of his artistic production on advancing the cause of the "One Big Union". Mr Block is a lot like Henry Dubb in that he thinks he and his boss share a common interest, yet Riebe introduced a hefty dose of slapstick, much like the popular comic strips of the day such as the Happy Hooligan or Krazy Kat. Seemingly indestructible, Mr Block constantly gets his block rapped by cops, thrown down stairs by private detectives, has bricks thrown at him by striking union men and is otherwise abused through his own foolish faith in the justness of the capitalist system. Wherever Mr Block goes he constantly misrecognizes friend and foe, such as the times when he takes up racist and sexist notions to illustrate how they fail the working class and serve the interest of exploitation. But so too Mr Block falls for what the IWW saw as the conciliatory delusion of the American Federation of Labor and Socialist Party electioneering, making Mr Block at times a divisively sectarian character. Despite this, the character Mr Block was widely embraced across the movements for his capacity to dramatize through comedy the power of class consciousness.

30. Joe Hill, Letters of Joe Hill, Philip Foner (ed.) (New York, I965), p. I6.

3I. Ernest Riebe, Mr. Block: Twenty-Four IWW Cartoons, Franklin Rosemont (ed.) (Chicago, IL, I984); Riebe produced two other Mr Block books: Mr Block and the Profiteers and Crimes of the Bolsheviki (Chicago, IL, I919). 
One Big Union Monthly, November 1919.

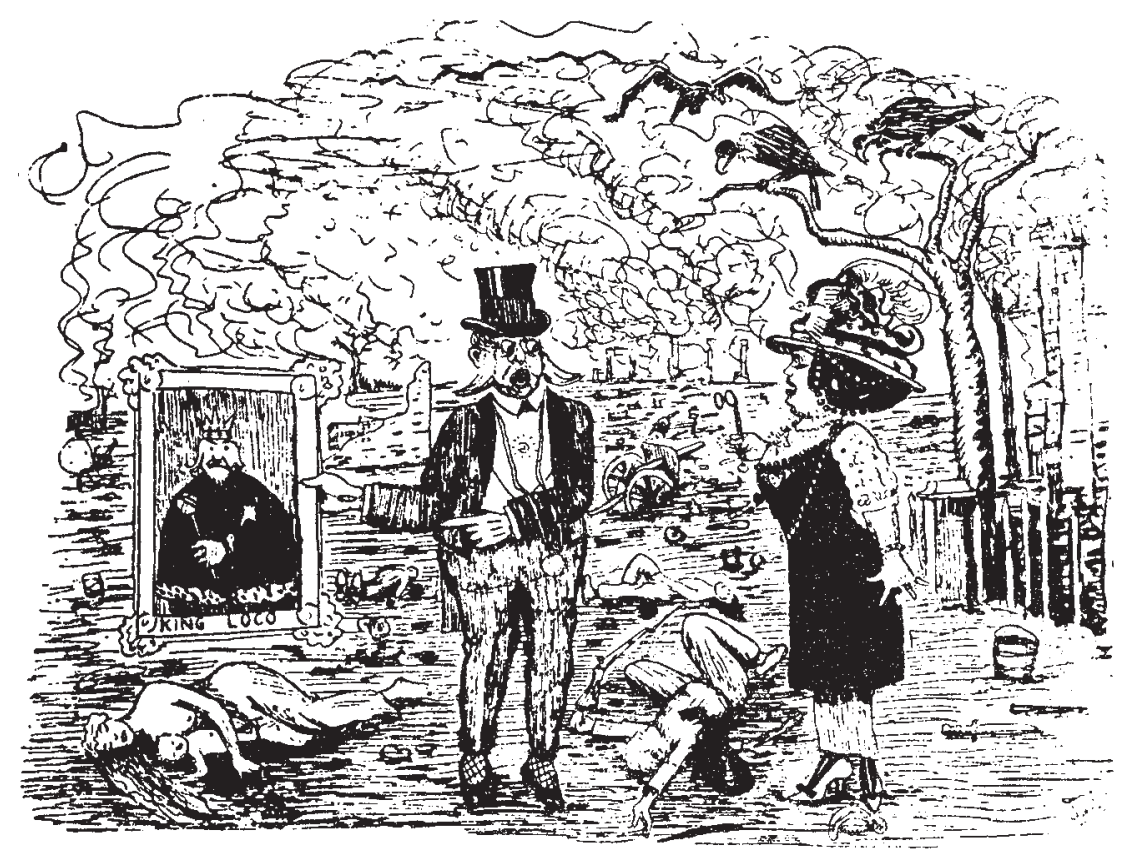

Mr. Highbrow: "These wars are terrible. Here they have shot a hole in this 2,000-year old painting."

Mrs. Highbrow: "Oh! Horrors! How thoughtless of that commander not to order some peasants to stand in front of it during the battle."

Figure ı. Joe Hill, "Mr and Mrs Highbrow", One Big Union Monthly (November 1919). This cartoon was probably drawn in I9I0 or I9I I, but first published after Hill's execution.

\section{CONCLUSION}

Like the ideals of Art Young and the pages of the Appeal to Reason, the IWW had grand economic and cultural ambitions: "we are forming the structure of the new society within the shell of the old". In this project it was clear that cartoons and humor had a large role to play, not just in keeping social movement participants in good spirits, but in framing the popular radical movement and visualizing its ideological contours. Radicals found cartoons to be uniquely suited to challenging the values of the capitalist enemy while envisioning a new set of ideologies and institutions with which to replace the old. Young, Walker, Riebe and others attempted this radical project of making the new in the shell of the old by remaking the cultural form of the editorial cartoon or comic strip, 


\section{MR. BLOCK}

\section{HE MEETS OTHERS}
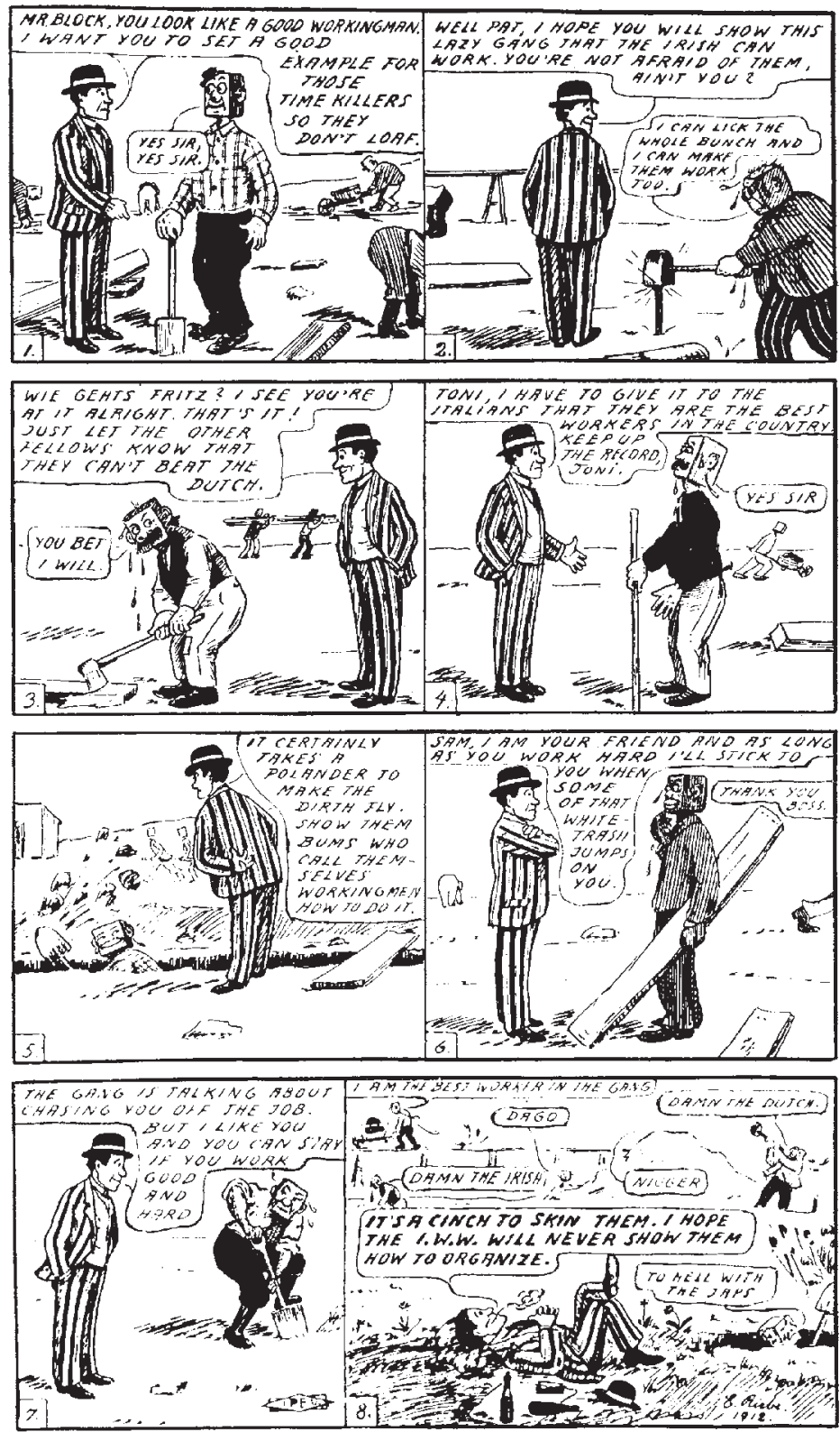

Figure I I. Ernest Riebe, "Mr Block: He Meets Others", Mr Block: Twenty-Four IWW Cartoons (1913; repr. Chicago, IL, I984). 


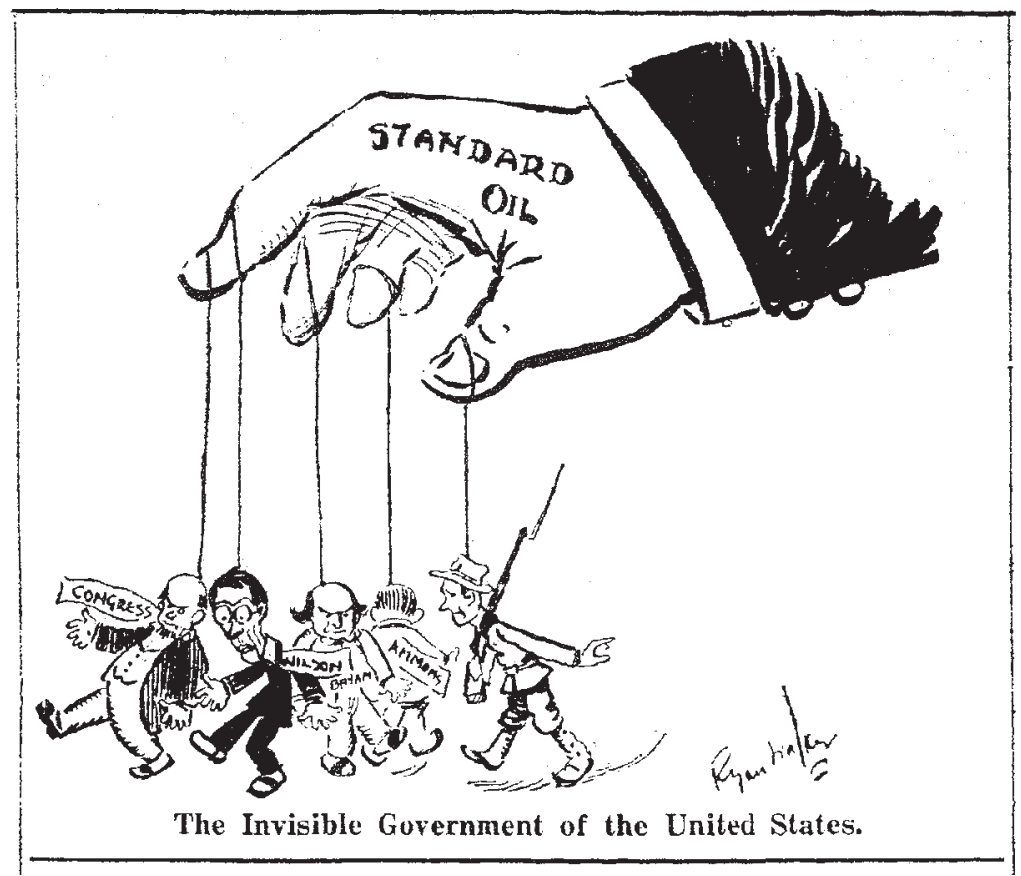

Figure I 2. Ryan Walker, "Invisible Government", Appeal to Reason, I6 May 1914. Here the "invisible hand" of the capitalist market is replaced by the very visible, manipulating hand of John D. Rockefeller's Standard Oil Trust, pulling the strings of presidents, soldiers and congress into an aggressive war against Mexico.

transforming it from a narrowly partisan political medium or harmless source of entertainment into a major vehicle of radical mass communication and class-conscious humor. In this sense, the cartoon humor of Art Young, Ryan Walker or the IWW was truly "radical", not just in its commitment to working-class revolution, but in its efforts to illustrate through abstraction the sources of social conflict, to expose the roots of capitalist inequality, and in so doing, build a revolutionary social movement.

In humor the popular radical movements found solidarity, in comedy they found the strength to name and ridicule the capitalist enemy, and through their ironic, angry, energetic cartoons they found a class politics of laughter which could illustrate the common values that held them together as a movement. And in taking on this ambitious political project through such simple means, especially in an era of global imperialism, corporate dominance, war and political repression, the cartoonists of the early twentieth century have found a renewed relevance for our own time. 